奋の銅塊から压延された鋼片あるいはビレットの縦疵の 状況とから，綃症の原因として問題になる表面気泡の位 置や，気泡の深さと縱庇の深さとの関俰およびスケール オフにともなう気泡の酸化状淏などを明にして，縦㾟防 止のための眖酸度調節上の考とした．結果を要約すれ は,

（1）スケールオフによる表面気泡の露出のための気 泡底の酸化は省略して考えても差支えない程度である.

（2）熱塊で均熱师に送付される一般の作業状況にお いては鎆片の縦疵の原因とならないためには，表面気泡 銅塊の肌から $1 \mathrm{~mm}$ 以内, せいせ゚い $2 \mathrm{~mm}$ 以内に収る ようにするか，あるいは肌から $4 \mathrm{~mm}$ 以上，安全さを 見込んで $5 \mathrm{~mm}$ 以上奥にあるようにすべきである.

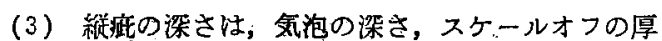
さおよび死延比から考えられるよりは若千㳿目になる ようである。

(ただし銅片の面と隅角とで，症深さが異るようであ ることもこの一因として考えられるので，詳細は後報に
て検討の子定である.)

（4）圧延が進めば縱㾟はその深さが減少するはもち ろん，その数も減少する.

本報の結果乙第 I 報の結果とをあすせ考光れば，綐疵 を調節すべき脱酸度が求められるわけであるが，この点 については，さらに注入速度などの影響を明らかにして から考察する予定である。

なお本研究は第 I 報で述べた諸氏の御指導, 御協力に よる他, 気泡の酸化実験は当所, 製鋼研究課, 森久君が 担当した。（昭和 32 年 5 月寄稿）

\section{交献}

1) 加藤 健：鉄々鎆，43 (1957) No. 10, 1104

2) 大黒竹司，他：鉄々銅，39 (1953) No.9, 973

3）守川喜久堆，他：鉄之錀，40 (1954) No. 3, 313

4) 大竹 正, 他: 製鉄研究, 211 (1955) 938

5 ）茂木洸助：鉄と銿，41 (1955) No. 3, 266

6) C. L. Mevette, V. E. Elliott: Trans. A.I.M.E. 176 (1948) 201

熔融鉄炭素合金の脱炭反応に関する研究 $(\mathrm{IV}$ )

（水蒸気による脱炭反応について）

勝藤 昌 伸**

\title{
STUDIES ON THE DECARBURIZATION REACTION OF MOLTEN Fe-C ALLOYS (IV)
}

\author{
(On the Decarburization Reaction with Water Vapour)
}

\section{Yoshinobu Katsufuji}

Synopsis:

The rates of carbon removal of molten $\mathrm{Fe}-\mathrm{C}$ alloys containing $0.5 \sim 4 \% \mathrm{C}$ with water vapour of $\mathrm{H}_{2}-\mathrm{H}_{2} \mathrm{O}, \mathrm{O}_{2}-\mathrm{H}_{2} \mathrm{O}$ gas system were measured by flow method.

The results obtained were as follows.

In the system of $\mathrm{H}_{2}-\mathrm{H}_{2} \mathrm{O}$ gas mixture, the rates of carbon removal were proportional to the partial pressure of water vapour between 7 and $32 \mathrm{mmHg}$. The dissolved oxygen in the melt during the reaction was independent of the pressure of water vapour and in some degree higher than the equilibrium value. From these results the reaction was considered to take place on the interface. The specific rate constant was somewhat smaller than that with oxygen gas of the same pressure. The increased amounts of the carbon removal with Water vapour in the addition of water vapour to oxygen gas were influenced by oxygen gas pressure. The oxidation of carbon monoxide formed to carbon dioxide in the carbon reaction with oxygen gas was remarkable, but in the presence of water vapour this oxidation almost did not take place.

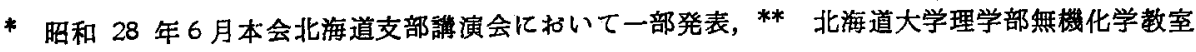




\section{I. 緒带}

熔鉄に熔解する炭素の酸素ガスによる脱炭反忘につい て，その反応機構を速度論的立場から検討した結果を既 に報告した(123834) 本報告で注酸化性ガスとして水蒸気を 用い，水素，水蒸気混合ガスおよび酸素，水蒸気混合ガ スによる脱布反応の反応速度を測定してえられた結果か ら，この系の脱炭反応の機構を酸素ガスの場合と比較検 討した。

溶融鉄炭素合金に $\mathrm{H}_{\mathbf{2}}-\mathrm{H}_{2} \mathrm{O}$ 混合ガスを反応せしめる とき纪起りらる諸反応として次式が考えられる，すなわ b

$$
\begin{aligned}
& \mathrm{H}_{2} \mathrm{O} \text { (gas) } \rightleftarrows \mathrm{H}_{2} \mathrm{O} \text { (ads.) } \\
& \mathrm{H}_{2} \mathrm{O} \text { (ads.) } \rightleftarrows \mathrm{H}_{2}(\mathrm{~g})+\mathrm{O} \text { (diss.) } \\
& \underline{\mathrm{C}}+\underline{\mathrm{O}} \rightarrow \mathrm{C} \mathrm{O} \\
& \mathrm{C}+2 \mathrm{O} \rightarrow \mathrm{CO}_{2} \\
& \mathrm{CO}+\mathrm{H}_{2} \mathrm{O} \rightarrow \mathrm{CO}_{2}+\mathrm{H}_{2} \\
& \mathrm{C}+2 \mathrm{H}_{2} \rightarrow \mathrm{CH}_{4}
\end{aligned}
$$

こ〉で（1）式注水蒸気の熔鉄上に括ける吸着を表わ 乙，（2）式は吸着した水蒸気の熔鉄界面での溶解を表 わす（3）拈よ゙（4）式は（1）（2）反応によつて 生成する酸素原子と熔鉄に溶解する炭素との間の反応て あり，(5) 式注（3）および（4）式によって生成し た $\mathrm{CO}$ おび $\mathrm{CO}_{2}$ と $\mathrm{H}_{2}, \mathrm{H}_{2} \mathrm{O}$ ガス間の反応，(6) 式は溶解炭素と，共存する水素ガスとの反応を表わす， (3)，(4)，(6) 式の反応によつて生成するガスは $\mathrm{H}_{2}$ $\mathrm{H}_{2} \mathrm{O}$ 混合ガスで絶えず系外に取り出されるような条件 におかれているので，いずれも正方向の反応のみを考虑 すればよい。

$\beta$ graphtie $と \mathrm{H}_{2}, \mathrm{CH}_{4}$ 間の平衡注 $2 \mathrm{H}_{2}$ $+\mathrm{C}(\beta)=\mathrm{CH}_{4}$ であらわされるが，この反応 の遊離エネルギー変化占梳 $\Delta \mathrm{F}^{0}=-21,550+$ 26・16T であたえられているので，この式を 用いて $1600^{\circ} \mathrm{C}$ 亿打ける平衡恒数をる上的る と $\mathrm{K}=6.2 \times 10^{-4} \mathrm{~atm}$. となり， $\mathrm{H}_{2} 1$ 気圧 における $\mathrm{CH}_{4}$ の平衡圧に相当する黑鉛方熔 鉄に溶解すると，宸素濃度の低下とともにそ の活動量性減少するから?7，熔鉄中の炭素上 平衡する $\mathrm{CH}_{4}$ の平衡压はさらに減少する。 また E. T. Turkdogan 等初の研究結果汇 よると, 1 気圧の $\mathrm{H}_{2}$ と炭素漲度 2〜4\% の

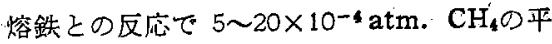
衡压をうるのに 4〜10 時間を要しているこ 之から $\mathrm{CH}_{4}$ の生成速度注著しく小さいむ
のとみなしてよい。したがつて (6) 式の反応速度は (3)，(4)，(5) 式の反応速度に比し無視し得るむの上 考克， $\mathrm{CO}$ 扎よび $\mathrm{CO}_{2}$ の単位時間における生成量の及 を測定して脱炭速度をもとめた.

$\mathrm{O}_{2}-\mathrm{H}_{2} \mathrm{O}$ 混合ガスによる反応では，酸素がス沉つけて は次式であたえられる。

$$
\begin{array}{lll}
\frac{1}{2} \mathrm{O}_{2} & \rightarrow & \mathrm{O} \\
\frac{\mathrm{c}}{\mathrm{c}}+\frac{\mathrm{O}}{2} \rightarrow & \rightarrow & \mathrm{CO} \\
\underline{\mathrm{O}}+2 & \rightarrow \mathrm{CO}_{2} \\
\mathrm{CO}+\frac{1}{2} \mathrm{O}_{2} \rightarrow \mathrm{CO}_{2}
\end{array}
$$

また水蒸気では前述の（1）（6）式方適用される.

\section{II. 実験装置および実験方法}

実験装置：実験装置の概略を Fig. 1 に示す。（A)洁 透明石英の反応管，(B)は高周波電気炉である. 坩堝性 高アルミナ質のタンマン管で，その内径は $20 \mathrm{~mm}$ ，深 さ $100 \mathrm{~mm}$ のもので，この中にあらかじめ熔製した所 要炭素濃度の鉄炭素合金を入れ，図のごとく装置を連結 する. (C) 恒温槽でこの中に 3 個の水蒸気飽和恆引゙入 れてある.ガス溜から流した水素ガスを順次 $\mathrm{H}_{2} \mathrm{SO}_{4}$, $\mathrm{KOH}, 450^{\circ} \mathrm{C}$ 亿加熱した還元銅， $\mathrm{CaCl}_{2} ， \mathrm{P}_{2} \mathrm{O}_{5}$ を通乙 て洗浄後恒温槽に入れ，所要温度の水蒸気圧に飽和せ乙 めたものを反応管に導く，反応管と水蒸気飽和瓶の間性 ニクロム線で加熱して水蒸気の凝縮するのを防いだ.

実験方法：測定にあたつては反応管内を充分に真空に し， $\mathrm{H}_{2}-\mathrm{H}_{2} \mathrm{O}$ 混合ガスを導入して試料を加熱溶解する. ガス流速は 150〜200cc/mn に一定とした．反応たる

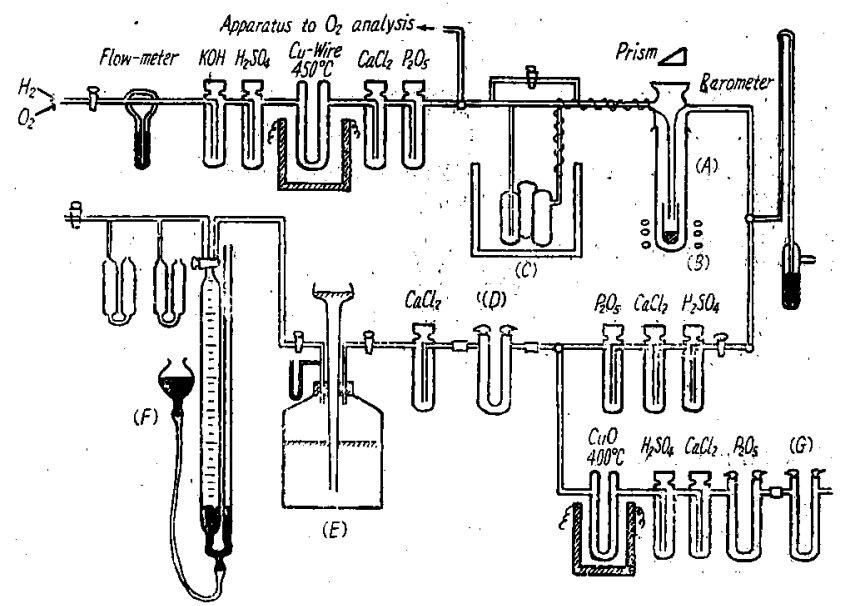

Fig. 1. Apparatus. 
つて生成するガスは $\mathrm{H}_{2} \mathrm{SO}_{4}, \mathrm{CaCl}_{2}, \mathrm{P}_{2} \mathrm{O}_{5}$ 至通して未 反応の水蒸気を洗浄後、ソーダライムの入つた吸収瓶 (D)で $\mathrm{CO}_{2}$ を吸収し，さらに残余のガスを捕集瓶 (E) に捕集する. 反态開始後 45 分経過したら熱源を断つた 陚料を急速に椧却せしめ，なお装置内に残存するガスる 完全に（E）中に捕集し，その全容量を正確に測つたまう <.

生成ガスの分析：捕集瓶の中のガスが均一江混合され るのをまつて，その約 100cc をガスビュレット（F）汇 採取しオルザット型ガス分析装置でまず $\mathrm{O}_{2}$ きつぎ Co 定量する. 吸收液は $\mathrm{O}_{2}$ はアルカリ性ピロガロー

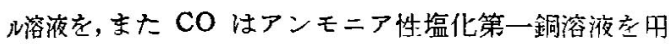
いた．瓦斯ビニレットによる吸収量と捕集したガスの既 知容量とから生成ガスの全容量をるとあた. $\mathrm{O}_{2}$ : は全実 㹂についてほとえど認められなかつた． $\mathrm{CO}_{\mathrm{a}}$ は (D) に 附したソーダライム入りU字管を科量してるとめた。

$\mathrm{O}_{2}-\mathrm{H}_{2} \mathrm{O}$ 混合ガスによる反応の場合には前報1上同栚 の方法により， $\mathrm{O}_{2}$ と $\mathrm{N}_{2}$ で所定の酸素分圧に調整した ガスをガス溜にたくわえ，これを洗浄後 (C) の恒温槽 在通して反応管に導く，生成ガスは $\mathrm{H}_{2} \mathrm{SO}_{4}, \mathrm{CaCl}_{2}$, $\mathrm{P}_{2} \mathrm{O}_{5}$ で脱水後, $\mathrm{CuO}$ 触媒を通して，ソーダライム入 りU字管 $(G)$ に吸収せしめ科量し定量する.生成ガス中 $\mathrm{CO}$ と $\mathrm{CO}_{2}$ を別々に定量する必要のあるときに注 $\mathrm{CuO}$ の前と後にそれそれりーダライムの入つたU字管なが てまず $\mathrm{CO}_{2}$ を $\mathrm{CuO}$ の前のU字管で吸収せしわ，つき $\mathrm{RCuO}$ で $\mathrm{CO}$ 学 $\mathrm{CO}_{2}$ に酸化して同樣にU字管に吸収 せしめる方法によつた。

揤温にはあらかじめ純 $\mathrm{Fe}, \mathrm{Ni} ＼textrm{C u}$ で補正し去光高 温計を用いた。用いた試料の重量は約 $40 \mathrm{~g}$ である。

\section{III. 実 験 結 果}

$\mathrm{H}_{2}-\mathrm{H}_{2} \mathrm{O}$ 混合ガスについて: 水蒸気压 7 32 $\mathrm{mmHg}$, 孷素初浱度 $0.5 \sim 4 \% \mathrm{C}$, 反応温度 $1580^{\circ} \mathrm{C}$ の条件下に おける水蒸気压之脱炭速度との関係を Fig. 2 K示す. 前述の方法によつて得られた $\mathrm{CO}$ と $\mathrm{CO}_{2}$ から反応時 間 45 分間に生成したCOガスの全容量をるとめ, これ 安䛨料中の炭索浱度を表わす重量百分率飞換算したもの， を盼炭量とし図中縱軸に示した。同図から明らかなよう に脱炭速度は一定炭素浱度の下では水蒸気圧に注ほ比例 する. 水蒸気圧をさらに高くすると, 反応管上部の二ク 口么線で直接加熱出来ない部分に水蒸気がやや凝縮する のを認めたので実測値は図に示す水蒸気庄の範囲に限定 lた.

$\mathrm{CO}_{2}$ の生成量は $0.001 \sim 0.002 \mathrm{~g} / 45 \mathrm{mn}$ で炭素浱度
に換算して $0.0007 〜 0.0014 \% \mathrm{C} / 45 \mathrm{mn}$ であり，炭素澡 度, 水蒸気圧に関係なくほぼ一定値示す。す交わ方 $\mathrm{CO}_{2}$ の生成量はき和めて少量で，生成する $\mathrm{CO}$ 比し ほとえど無視し得る量である。このことは前述の可能な 反応式中（4）および（5）式の反応速度は小さく，主 反応は（3）式の反応であること示している.Fig.2 の関係は（4）および（5）式の副反応を卧とえどとも わずに（1）(2)(3) 式の反応が定量的に起つていて, 気相と熔鉄界面で水蒸気の平衡が成立しているこ上示 すをのである.

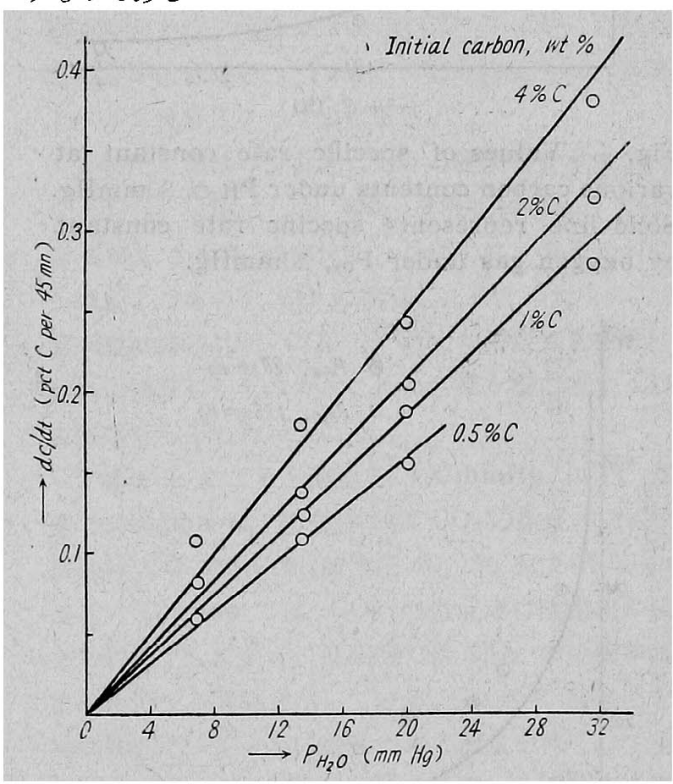

Fig. 2. Relation between rate of carbon removal and partial pressure of water vapour at $1583^{\circ} \mathrm{C}$.

Fig. 2 の関倸から, 各宸素浱度, 各水蒸気压に方活 る速度恒数 $k_{0}$ をさきに得られた方法122ににたがつて 算出し, 水蒸気压との関係をもとめると, 一定炭素濃度 の下では $k_{0}$ は水蒸気压に比例する関係が得ら机宁. 水 蒸気压 $20 \mathrm{mmHg}, 0.5,1 ， 2 ４ \% \mathrm{C}$ に打ける $k_{0}$ 完者 こめると Fig. 3 に示す各点となり，炭素浱度の低下之 上もに $k_{0}$ 憎大するが，この傾向は酸素ガスの場合之 ほほ同一である.困中曲線は酸素生 $20 \mathrm{mmHg}$ の酸素ガ スによる $k_{0}$ の値を図示したもので，水蒸気による脱炭 速度恒数は同压の酸素による速度恒数に比してやや小き 值走示している.

脱炭過程の溶解酸素は反応管上部の側管にあらかじる 搟入してある純アルミニウム棹を磁石を用いて, 反応終 了と同時に熔鉄上に落下゙せしめ，急冷した試料中の 


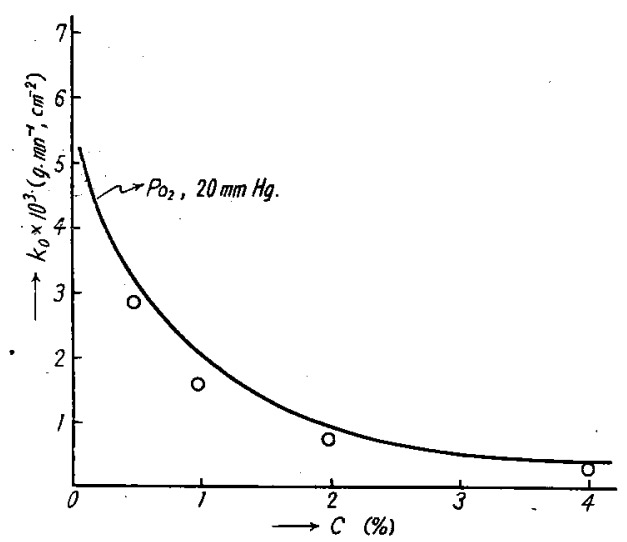

Fig. 3. Values of specific rate constant at various carbon contents under $\dot{\mathrm{P}}_{2} \mathrm{O}, 20 \mathrm{mmHg}$. Solid line represents "specific rate constant by oxygen gas under $\mathrm{P}_{\mathrm{O}_{2}}, 20 \mathrm{mmHg}$.

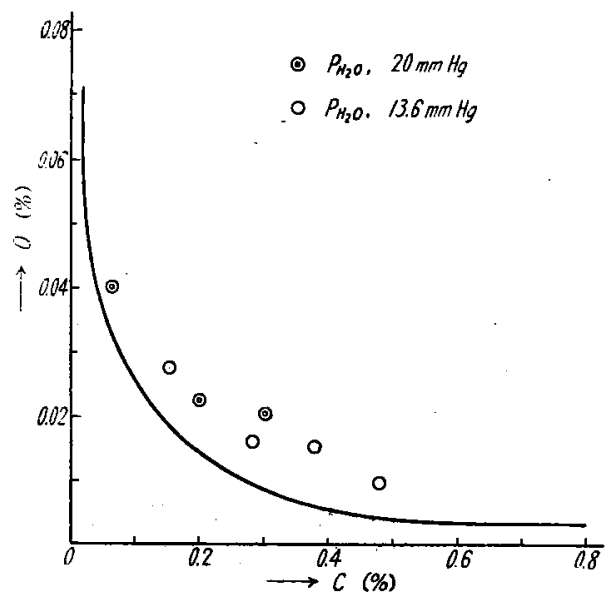

Fig. 4. Dissolved oxygen in the process of decarburization.

Solid line represents Vacher-Hamilton's equilibrium values.

$\mathrm{Al}_{2} \mathrm{O}_{3}$ を定量してもとめた. Fig. 4 に示すごとく溶解 酸素は水蒸気圧に無関係に Vacher-Hamilton の平衡 值よりむやや大きな值である.酸素ガスの場合に溶解酸 秦が酸素圧に無関係に一定であることおよび両ガスとも 溶解酸素量がほぼ同一の值を示すことから, 水蒸気によ る脱炭反応の場合にる酸素ガスによる反応と同様に界面 で起る反応が主反応で，熔鉄中に溶解する酸素任炭素之 定学状態を保らつ〉变化しているものと考えられる。

$\mathrm{O}_{2}-\mathrm{H}_{2} \mathrm{O}$ 混合ガスについて: 酸素圧 $150 \mathrm{mmHg}$ の酸 素ガスに所定の水蒸気を混合したガスによる脱炭速度は 酸素ガスのみによる眖炭速度に比し增大する・したがつ
て水蒸気を酸素に添加したガスによる脱炭量から，同一 条件で別に行つた酸素ガスのみによる脱炭量を差引いた むのを水蒸気による眖炭増量とみなし，この脱炭増量を $\Delta C$ と置いてこれを縱軸にとり水蒸気圧との関係をると めた結果が Fig. 5 である. 図からかかるように脱炭速 度忹水蒸気の共存によつて堌大するが， その堌量は実測 筙囲の水蒸気圧では圧によつてあまり変化がなく，1\% Cでは 0.06〜0.09\% C /45mn，2\%C では 0.09〜0.12 $\% \mathrm{C} / 45 \mathrm{mn}, 4 \% \mathrm{C}$ では逆に減少して 0.06\% C/45mn 崫 である.

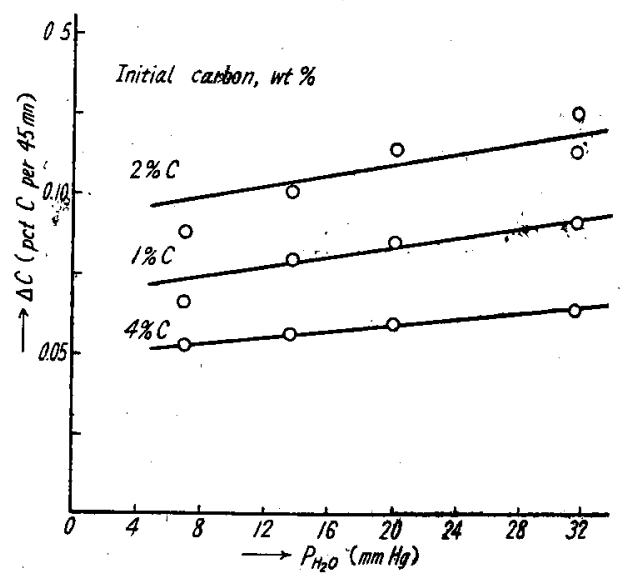

Fig. 5. The increased amounts of carbon removal with water vapour of various pressures in the addition of water vopour to oxygen gas of $150 \mathrm{mmHg}$ pressure.

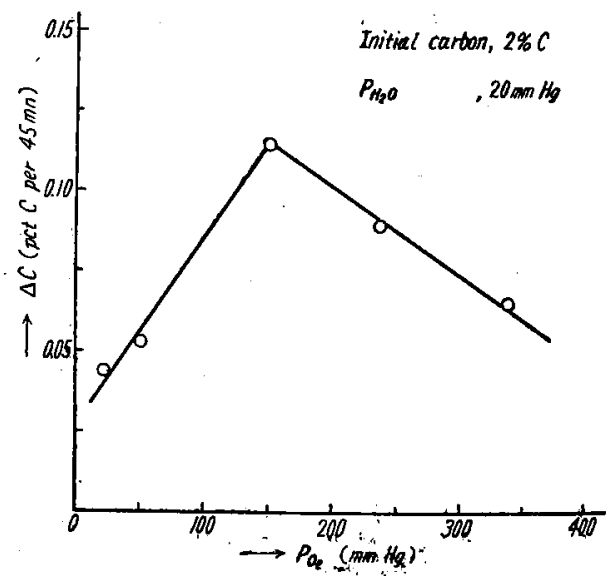

Fig. 6. The increased amounts of carbon removal with water vapour of $20 \mathrm{~mm}$ pressure under the various oxygen pressures.

つぎに水蒸気圧を $20 \mathrm{mmHg}$ に一定どし，酸素压を 
20〜340 $\mathrm{mmHg}$ に变化ざせときの脱炭增量をもとめ た結果が Fig. 6 である.酸素生が $150 \mathrm{mmHg}$ から, $240 \mathrm{mmHg}, 340 \mathrm{mmHg}$ に增加するにしたがつて水蒸 気死は $20 \mathrm{mmHg}$ に一定であるにかかわらず脱炭増量 は減少する．また酸秦压索 $20,50 \mathrm{mmHg}$ のごとく低 くすると眖炭增量は $0.05 \% \mathrm{C} / 45 \mathrm{mn}$ 位に減少する.

\section{IV. 考察}

i） $\mathrm{O}_{2}-\mathrm{H}_{2} \mathrm{O}$ 混合ガスによる反応について：酸素およ び水蒸気がそれでれ単独に存在し反応する場合の脱炭速 度式は実驜結果ふら次式であたえられる。

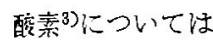

$$
\begin{aligned}
& -\frac{d[\mathrm{C}]}{d t}=k_{1} \cdot \mathrm{A} \cdot \mathrm{Po}_{2}{ }^{1 / 2} \cdot f[\mathrm{C}]
\end{aligned}
$$

亦蒸気については

$$
-\frac{d[\mathrm{C}]}{d t} k_{2} \cdot \mathrm{A} \cdot \mathrm{PH}_{2} \mathrm{O} \cdot f[\mathrm{C}]
$$

こつて $k_{1} ， k_{2}$ はそれでれの速度恒数，A $\mathrm{A}$ 界面積， $\mathrm{PO}_{2}, \mathrm{PH}_{2} \mathrm{O}$ はそれぞれのガスの分王， $f$ は速度恒数の 浱度依存の度合をあらわす倸数で両者ほ医等しい，今酸 素水蒸気を添加したガスによる反応が両ガスについて 独立沪起るものとすると，その反応速度は次式であたえ 度宗.

$$
-\frac{d[\mathrm{C}]}{d t}=\left(k_{1} \mathrm{Po}_{2}+k_{2} \mathrm{PH}_{2} \mathrm{O}\right) \mathrm{A} f[\mathrm{C}]
$$

しふるに Fig. 5 に示されるように $\mathrm{O}_{2}-\mathrm{H}_{2} \mathrm{O}$ 混合ガ スによる脱炭增量は（9）式が成立するものとすれば (8) 式の反応すなわち Fig. 2 に示した $\mathrm{H}_{2}-\mathrm{H}_{2} \mathrm{O}$ ガ スによる脱炭量に相当すべきであるが，実測值はこれよ 方低傗を示し，かつ水蒸気圧に無関係にほぼ一定値 と心つている．両ガスを比較すると $k_{1}$ は $k_{2}$ に比し大 言々，毛た酸素圧は水蒸気圧に比し大である。したがつ

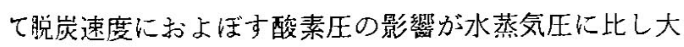

きくなるため，Fig. 5 に示すように水蒸気 压と脱炭增 量の関係は $\mathrm{H}_{2}-\mathrm{H}_{2} \mathrm{O}$ 系の場合のような定量的な関係が

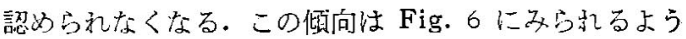
に酸素压の増大とともにいちじるしくなる.

酸素圧が $50 \mathrm{mmHg}$ の場合および $150 \mathrm{mmHg}$ で 4 $\% \mathrm{C}$ の場合には前報莎したように，反応時間しとも に速度恒数注減少する。この系に水蒸気を添加した場合 に脱炭增亩が少いのは，このような速度恒数の減少の影 響によるものと考えられる。

ii）生成するCO ガスの酸化について：酸素による 脱炭反応では, 生成ガス中の $\mathrm{CO}$ と $\mathrm{CO}_{2}$ の割合柱反 応の条件に依存し，Table 1 に示すように，酸素压お よびガス流量によつて変化する.

表中第 4 攔は 45 分間における脱炭量を示すが，こ〉 で $\mathrm{CO}(\mathrm{g})$ は生成した $\mathrm{CO}_{2}$ を吸収後残余の $\mathrm{CO}$ ガス を $\mathrm{CuO}$ で $\mathrm{CO}_{2}$ に酸化し，こ机をソーダライムに吸収 乙秤聂したものを $\mathrm{CO}$ に㒜算してもとめたものである。 第 5 欄は得られた $\mathrm{CO}_{2}$ と $\mathrm{CO}$ の脱炭重量を試料中の $\mathrm{C} \%$ に換算したもので，これから第6闑に示寸 $\mathrm{CO}_{2}$ の 生成率家もとめた。

Table 1 によると酸素圧 $150 \mathrm{mmHg}$ 以上, ガス流 速 $150 \mathrm{cc} / \mathrm{mn}$ 以上の条件では $\mathrm{CO}_{2}$ の生成率は約 $90 \%$, 残余注 CO であるが,酸素圧 $20 ， 50$ および $90 \mathrm{mmHg}$ 流速 $150 \mathrm{cc} / \mathrm{mn}$ で注 $\mathrm{CO}_{2}$ の生成率注酸素圧の隇少と ともに低下してゆく，低圧側では $\mathrm{CO}_{2}$ の生成率は酸素 圧に比例する関係を示している.つぎ酸素圧を 150 $\mathrm{mmHg}$ に一定とし, 酸素ガスの流量它低くしてゆくと 次第に $\mathrm{CO}_{2}$ の生成慗は減少するが，その減少の度合は 生成する CO 量にほぼ比例する関俰を示している。以 上の結果を浾足せしめる $\mathrm{CO}_{2}$ の生成速度, $v$ は次式で あたえられる。

$$
v=k \frac{\mathrm{P}_{\mathrm{O}_{2}}}{\mathrm{P}_{\mathrm{CO}}}
$$

\begin{tabular}{|c|c|c|c|c|c|c|c|c|}
\hline $\begin{array}{l}\text { Initial carbon } \\
\text { content }\end{array}$ & $\mathrm{Po}_{2}$ & Flow rate & $\begin{array}{r}\text { Decarbu } \\
(\mathrm{g} /\end{array}$ & amount & Decar & $\begin{array}{l}\mathrm{ized} \text { a } \\
/ 45 \mathrm{mn}\end{array}$ & unt & $\begin{array}{c}\text { Ratio of } \\
\mathrm{CO}_{2}\end{array}$ \\
\hline $\mathrm{C}(\%)$ & $(\mathrm{mmHg})$ & $(\mathrm{cc} / \mathrm{mn})$ & $\mathrm{CO}_{2}$ & $\mathrm{CO}$ & $\mathrm{CO}_{2}$ & $\mathrm{CO}$ & Total & $(\%)$ \\
\hline $\begin{array}{l}4 \cdot 2 \\
4 \cdot 2 \\
4 \cdot 2 \\
1 \cdot 0 \\
1 \cdot 0 \\
1 \cdot 0 \\
1 \cdot 0 \\
1 \cdot 0 \\
4 \cdot 2\end{array}$ & $\begin{array}{r}150 \\
150 \\
150 \\
150 \\
90 \\
52 \\
20 \\
20 \\
240\end{array}$ & $\begin{array}{r}150 \\
50 \\
30 \\
150 \\
150 \\
150 \\
150 \\
150 \\
150\end{array}$ & $\begin{array}{l}1.469 \\
0.673 \\
0.228 \\
1.044 \\
0.633 \\
0.301 \\
0.086 \\
0.065 \\
2 \cdot 005\end{array}$ & $\begin{array}{l}0.096 \\
0.328 \\
0.288 \\
0.104 \\
0.157 \\
0.176 \\
0.223 \\
0.283 \\
0.153\end{array}$ & $\begin{array}{l}0.999 \\
0.464 \\
0.154 \\
0.712 \\
0.433 \\
0.205 \\
0.059 \\
0.044 \\
1.353\end{array}$ & $\begin{array}{l}0 \cdot 103 \\
0 \cdot 356 \\
0 \cdot 307 \\
0 \cdot 112 \\
0 \cdot 169 \\
0 \cdot 188 \\
0 \cdot 239 \\
0 \cdot 303 \\
0 \cdot 162\end{array}$ & $\begin{array}{l}1 \cdot 102 \\
0 \cdot 821 \\
0 \cdot 461 \\
0 \cdot 824 \\
0.602 \\
0 \cdot 393 \\
0 \cdot 298 \\
0.347 \\
1 \cdot 515\end{array}$ & $\begin{array}{l}90 \cdot 65 \\
56 \cdot 51 \\
33 \cdot 50 \\
86 \cdot 41 \\
71 \cdot 92 \\
52 \cdot 11 \\
19 \cdot 79 \\
12 \cdot 68 \\
89 \cdot 30\end{array}$ \\
\hline
\end{tabular}

Table 1. The oxidation of $\mathrm{CO}$ formed to $\mathrm{CO}_{2}$ in the carbon reaction with oxygen under the several conditions. 
こつで $P_{O_{2}}$ 法気相における酸秦の分圧, $P_{\text {co }}$ は一酸化 炭素の分王をあらわす。

をた一方酸素による脱炭反忘の速度恒数 $k_{0}{ }^{1) に つ い て ~}$ 屺次式が成立する。

$$
k_{0}=a \sqrt{\mathrm{P}_{2}}
$$

以上の絬果汇溶解炭素と酸素ガスの反応過程として, まず最初に $\frac{1}{2} \mathrm{O}_{2} \rightarrow \underline{\mathrm{O}}, \underline{\mathrm{C}}+\underline{\mathrm{O}} \rightarrow \mathrm{CO}$ の反応引起り，つぎ に主としてCOガスと気相の酸素との反応すすなわちCO $+\frac{1}{2} \mathrm{O}_{2} \rightarrow \mathrm{CO}_{2}$ の反応が気相，熔鉄界面，または反応管 内の磁器なごの器壁の界面で進行するこょ齐するので 水蒸気の場合上（4）式の反応がきわめて少いことか らもわかるように, $\mathrm{C}+2 \mathrm{O} \rightarrow \mathrm{CO}_{2}$ の反応は酸素の場合 にも僅少であると考えられる.

これに対して水蒸気では， $\mathrm{H}_{2}-\mathrm{H}_{2} \mathrm{O}$ 混合ガスの場合に 《, 前述のご々く $\mathrm{H}_{2} \mathrm{O} \rightarrow \mathrm{H}_{2}+\mathrm{O}, \underline{\mathrm{C}}+\mathrm{O} \rightarrow \mathrm{CO}$ の反応 が大部分で $\mathrm{CO}+\mathrm{H}_{2} \mathrm{O}-\rightarrow \mathrm{CO}_{2}+\mathrm{H}_{2}$ の反応はほとえど無 視し得る . た $\mathrm{O}_{2}-\mathrm{H}_{2} \mathrm{O}$ 混台ガスの場合には $\mathrm{CO}_{2}$ の生 成率は上述の酸素のみの場合乞ほ上んごかからない結果

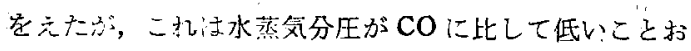
よび主こして（5）式の平衡9が反応温度でいちじるし． ‘くCO側に移行するこ上によるものと考えられる。

\section{V. 結言}

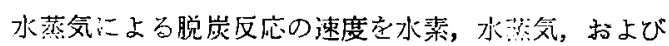
酸素, 水蒸気混台ガスによつて測定し，水督気の反応に 与る過程を明ら水してつ念の結果をえた。

㙂炭速度㲺水蒸気生 7〜32 $\mathrm{mmHg}$ 内で，ての生力に
比例する，

酸素ガスの場合と同様に，脱炭過程に溶解する酸素は 水蒸気圧に無関係に平衡値よりもやや高い値を示す. 以上のことから水蒸気による脱炭反応は界面反応が主 反応であるとみなされる。

水蒸気による脱炭速度恒数は同圧の酸素による速度恒 数に比しやや小さいが, 速度恒数の炭素荟度による变化 の傾向は酸素の場合とほぼ同一である.

酸素ガスに水蒸気を添加した場合の水蒸気による脱炭 增量は主として酸素压によつて影響をうける。

酸素ガスによる脱炭反応では反応によつて生成する $\mathrm{CO}$ ガスの気相酸素による $\mathrm{CO}_{2}$ への酸化がいらじるし いが, 水蒸気ではこの酸化がほとえど起らない。

終りに臨みご指導ご㗆達頂いた丹羽教授に感謝の意を 表する.（昭和 32 年 4 月寄稿）

\section{文献}

1) 勝藤, 丹羽: 鉄と鋼，40 (1954) 973

2) 勝藤，丹羽: 鉄と铜， 41 (1955) 412

3.).勝藤, 丹羽：鉄之銅，41 (1955) 500

4) 丹羽, 勝藤：日本金属学会誌，17（1953）271

5) F. D. Richardson: J. Iron Steel Inst., 175 (1953) 33

6) 三本木, 大谷：鉄と鋼，39 (1953) 483

7) F. D. Richordson and W. E. Dennis: Trans. Faraday Soc., 49 (1953) 171

8) E. T. Turkdogan, L. E. Leake and C. R. Masson: Actà Metallurgica, 4 (1956) No. 4

9) M. N. Dasteer and J. Chipman: Trans. A.I.M.E., 185 (1949) 444 